\title{
Sorafenib inhibited cell growth through the MEK/ERK signaling pathway in acute promyelocytic leukemia cells
}

\author{
YUNJIE ZHANG ${ }^{1,2^{*}}$, GANGCAN LI $^{1 *}$, XIN LIU ${ }^{2}$, YANPING SONG ${ }^{1}$, JIA XIE $^{1}$, GUANG LI ${ }^{1}$, \\ JINGJING REN $^{1}$, HAO WANG ${ }^{1}$, JIAO MOU $^{1}$, JINQIAN DAI ${ }^{1}$, FENG LIU $^{1}$ and LIANG GUO ${ }^{1}$ \\ ${ }^{1}$ Institute of Hematology, Xi'an Central Hospital, Xi'an, Shaanxi 710003; ${ }^{2}$ Department of Hematology, The First \\ Affiliated Hospital of Xi'an Jiaotong University School of Medicine, Xi'an, Shaanxi 710061, P.R. China
}

Received June 16, 2016; Accepted October 20, 2017

DOI: $10.3892 / \mathrm{ol} .2018 .8010$

\begin{abstract}
The present study assessed the mechanism underlying the effect of sorafenib on the proliferation and apoptosis of the acute promyelocytic leukemia (APL) cell line NB4. NB4 cells were treated with different concentrations of sorafenib $(0,1.5,3$, 6 , and $12 \mu \mathrm{M}$ ) for 24,48 and $72 \mathrm{~h}$. Cell proliferation, cell cycle, and apoptosis were analyzed using an MTT assay and flow cytometry analysis, respectively. Reverse transcription-semi-quantitative polymerase chain reaction and western blot analysis were performed to assess the expression of caspase-3, caspase-8, myeloid cell leukemia (MCL)1, cyclin D1, mitogen-activated protein kinase (MEK), phosphorylated (P)-MEK, extracellular signal-regulated kinase (ERK) and P-ERK. The results of the MTT assay demonstrated that, compared with untreated cells, the proliferation of sorafenib-treated NB4 cells was inhibited dose- and time-dependently. Furthermore, cell cycle arrest was induced in the G0/G1 phase and cell apoptosis was promoted in a dose-dependent manner in sorafenib-treated NB4 cells compared with untreated cells. In addition, the expression of the proapoptotic molecules caspase- 3 and caspase- 8 was significantly upregulated, and the expression of the antiapoptotic molecule MCL1 and the cell cycle-associated cyclin D1 was downregulated in sorafenib-treated NB4 cells compared with untreated cells. Furthermore, the phosphorylation of MEK and ERK was inhibited in sorafenib-treated NB4 cells compared with untreated cells. Sorafenib may inhibit proliferation and induce cell cycle arrest and apoptosis in APL cells. The underlying mechanisms of such effects may be associated with alterations to the expression of apoptosis-associated and cell
\end{abstract}

Correspondence to: Dr Xin Liu, Department of Hematology, The First Affiliated Hospital of Xi'an Jiaotong University School of Medicine, 277 Yanta West Road, Xi'an, Shaanxi 710061, P.R. China E-mail: liuxin59221@163.com

${ }^{*}$ Contributed equally

Key words: sorafenib, acute promyelocytic leukemia, cell proliferation, apoptosis, mitogen-activated protein kinase/extracellular signal-regulated kinase signaling pathway cycle-associated molecules via MEK/ERK signaling pathway inhibition.

\section{Introduction}

Leukemia is a malignant hematologic neoplasm that occurs at the level of hematopoietic stem cells, accounts for $\sim 5 \%$ of all malignancies, and is one of the most common types of cancer among children and adolescents (1). Acute promyelocytic leukemia (APL), a high mortality-associated subtype of acute leukemia, predominantly manifests as disseminated intravascular coagulation or hyperfibrinolysis-induced severe bleeding (2). Chemotherapy with all-trans retinoic acid, anthracycline antibiotics and arsenic trioxide is a typical treatment for leukemia, and has been widely used with satisfactory effect (3). However, due to different genetic phenotypes and repeated drug exposure, drug resistance has begun to decrease the effectiveness of chemotherapy and the overall survival time of patients with leukemia, including those with APL (4). Thus, developing chemotherapy drugs that may aid in the treatment of patients with APL despite the presence of drug resistance is crucial.

A previous study demonstrated that, via the regulation of downstream nuclear transcription factors, the recombinant activated factor (RAF)/mitogen-activated protein kinase (MEK)/extracellular signal-regulated kinase (ERK) signaling pathway is associated with the increased expression of the multidrug-resistant permeability glycoprotein, and may thereby induce drug resistance in leukemia cells (5). Sorafenib is an oral RAF kinase inhibitor, and has been used for the treatment of liver and kidney cancer (6). Sorafenib inhibits the RAF/MEK/ERK signaling pathway thereby suppressing tumor cell proliferation and angiogenesis (7). Multiple studies have demonstrated that sorafenib induces tumor cell apoptosis in numerous types of cancer, including hepatocellular carcinoma (8), melanoma (9) and human glioblastoma cells (10), and acute myelocytic leukemia (11). Numerous studies have focused on the clinical application of sorafenib in acute leukemia and have demonstrated that sorafenib may exert a satisfactory chemotherapeutic effect (12-14). However, the effects and underlying mechanisms of sorafenib on APL remain to be fully understood.

Therefore, in the present study, sorafenib was used to treat the APL cell line NB4. The effect of sorafenib on the cell 
cycle, proliferation and apoptosis were subsequently assessed. Furthermore, the present study examined the mechanisms underlying the effect of sorafenib on the proliferation and apoptosis of APL cells.

\section{Materials and methods}

Cell culture. The APL cell line NB4 was purchased from the Shanghai Institute of Biochemistry and Cell Biology (Shanghai, China) and subsequently maintained in RPMI-1640 medium supplemented with $10 \%$ fetal bovine serum $(10 \%$; both from Hyclone; GE Healthcare Life Sciences, Logan, UT, USA) in a $37^{\circ} \mathrm{C}$ humidified incubator with $5 \% \mathrm{CO}_{2}$. The cells in logarithmic phase were used in subsequent experiments.

MTT assay. NB4 cells with a density of $1 \times 10^{4}$ cells $/ \mathrm{ml}$ were cultured on a 96 -well plate (180 $\mu \mathrm{l} /$ well). On day two, multiple concentrations of sorafenib $(0,3,6$ or $12 \mu \mathrm{M} ; 20 \mu \mathrm{l} / \mathrm{well}$; Bayer AG, Leverkusen, Germany) were added onto wells and cultured for 24,48 or $72 \mathrm{~h}$. Cells were subsequently incubated with $10 \mu \mathrm{l}$ of MTT $(5 \mathrm{mg} / \mathrm{ml}$; Sigma-Aldrich; Merck KGaA, Darmstadt, Germany) for $4 \mathrm{~h}$ at the same time each day. Subsequently, $100 \mu 1$ of DMSO (KeyGen Biotech Co. Ltd., Nanjing, China) was added to solubilize the formazan crystals at room temperature. Zero (medium, MTT, DMSO) and blank holes were set up. The absorbance was measured as the optical density (OD) value at a wavelength of $492 \mathrm{~nm}$ on a microplate reader. The inhibition rate of cell proliferation was calculated as follows: 1-(Experimental OD-Blank OD)/(Negative control OD-Blank OD)x $100 \%$.

Flow cytometry. NB4 cells were treated with sorafenib at a final concentration of $0,3,6$ or $12 \mu \mathrm{M}$. Following treatment for 24 and $48 \mathrm{~h}$, cells were collected via centrifugation (180 x g for $5 \mathrm{~min}$ ) at room temperature. For subsequent cell cycle analysis, cells were fixed with precooled $75 \%$ ethanol at $4^{\circ} \mathrm{C}$ for $1 \mathrm{~h}$. Cells were then centrifuged ( $350 \mathrm{x}$ g for $6 \mathrm{~min}$ ) at room temperature and the ethanol was removed by washing with PBS. Cells were resuspended in $300 \mu \mathrm{l}$ of PBS and treated with $50 \mu \mathrm{g} / \mathrm{ml}$ ribonuclease A (Shanghai Sangong Pharmaceutical Co., Ltd., Shanghai, China) at $37^{\circ} \mathrm{C}$ for $30 \mathrm{~min}$. Subsequently, cells were maintained in propidium iodide (PI; KeyGen Biotech Co. Ltd.) in the dark at $4^{\circ} \mathrm{C}$ for $15 \mathrm{~min}$. A flow cytometer (BD Biosciences, Franklin Lakes, NJ) was used to detect the cell cycle. The Annexin V-fluorescein isothiocyanate (FITC) Apoptosis Detection kit was used to detect cell apoptosis (KeyGen Biotech Co. Ltd.). The collected cells were incubated with Annexin V-FITC and PI at $25^{\circ} \mathrm{C}$ for $15 \mathrm{~min}$ in the dark. Following incubation with Binding buffer (provided by the Annexin V-FITC Apoptosis Detection kit), cells were detected using the flow cytometer. The experiment was repeated three times.

Reverse transcription-semi quantitative polymerase chain reaction $(R T-s q P C R)$. Cells were treated with sorafenib at a final concentration of $0,3,6$ or $12 \mu \mathrm{M}$ for $48 \mathrm{~h}$. Subsequently, total RNA was extracted from the collected cells using TRIzol reagent (KeyGen Biotech Co. Ltd.) at room temperature for $15 \mathrm{~min}$ and measured using a UV spectrophotometer (BD Biosciences) at $\mathrm{A}_{260}$; cDNA was reverse transcribed from $1 \mu \mathrm{g}$
Table I. Primer sequences of MCL1, caspase-3, caspase-8 and GAPDH.

\begin{tabular}{|c|c|c|}
\hline Gene & Primer sequence $\left(5^{\prime} \rightarrow 3^{\prime}\right)$ & $\begin{array}{l}\text { Product } \\
\text { size (bp) }\end{array}$ \\
\hline MCL1 & $\begin{array}{l}\text { F: GCGACTTTTGGCTACGGAGA } \\
\text { R: ATGAGGTGAAAGCCGCGAAA }\end{array}$ & 246 \\
\hline Caspase-3 & $\begin{array}{l}\text { F: AGGAGCAGTTTTGTTTGTGTGC } \\
\text { R: TCGTGGACCAATAATAAGAA } \\
\text { CCG }\end{array}$ & 123 \\
\hline Caspase- 8 & $\begin{array}{l}\text { F: GGGGCTTTGACCACGACCT } \\
\text { R: GTTTGCTCTATATAGGGCCTA } \\
\text { CTC }\end{array}$ & 368 \\
\hline GAPDH & $\begin{array}{l}\text { F: ACGGGAAACCCATCACCATC } \\
\text { R: CTACCACTACCCAAA GGGCA }\end{array}$ & 129 \\
\hline
\end{tabular}

MCL, myeloid cell leukemia; F, forward; R, reverse.

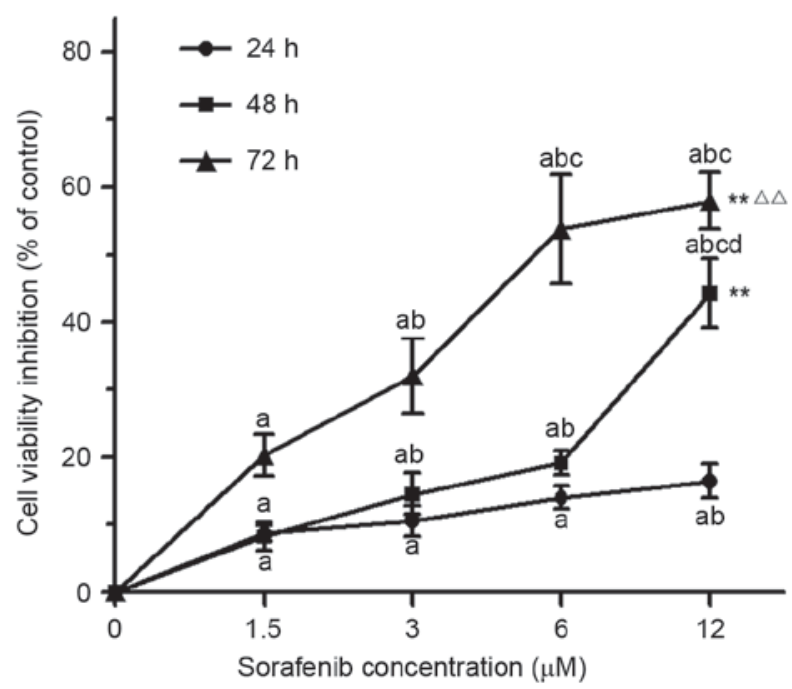

Figure 1. Inhibition rate of NB4 cell proliferation by different concentrations of sorafenib. The results of the MTT assay demonstrated that sorafenib significantly inhibited the proliferation of NB4 cells following treatment for 24,48 or $72 \mathrm{~h}$. ${ }^{* *} \mathrm{P}<0.01$, compared with the $24 \mathrm{~h}$ treatment; ${ }^{\Delta \Delta} \mathrm{P}<0.01$, compared with the $48 \mathrm{~h}$ treatment; a $\mathrm{P}<0.05$, compared with the $0 \mu \mathrm{M}$ sorafenib treatment; ${ }^{\mathrm{b}} \mathrm{P}<0.05$, compared with the $1.5 \mu \mathrm{M}$ sorafenib treatment; ${ }^{\mathrm{c}} \mathrm{P}<0.05$, compared with the $3 \mu \mathrm{M}$ sorafenib treatment; ${ }^{\mathrm{d}} \mathrm{P}<0.05$, compared with the $6 \mu \mathrm{M}$ sorafenib treatment.

of total RNA with $\mathrm{A}_{260} / \mathrm{A}_{280}$ of 1.8-2.0 using a PrimeScript RT reagent kit with a genomic DNA eraser (Takara Biotechnology Co., Ltd., Dalian, China) at $37^{\circ} \mathrm{C}$ for $15 \mathrm{~min}$, followed by $65^{\circ} \mathrm{C}$ for $15 \mathrm{sec}$. Briefly, $10 \mu \mathrm{l}$ of reaction system included: $2 \mu \mathrm{l}$ 5x PrimeScript RT master mix, $7 \mu 1$ RNase-free water and $1 \mu$ l RNA. Reverse cDNA was then used in sqPCR. Primer sequences corresponding to caspase-3, caspase-8, myeloid cell leukemia (MCL)1 and GAPDH are provided in Table I. The sqPCR reaction system was comprised of $1 \mu \mathrm{l}$ of cDNA, $0.25 \mu \mathrm{l}$ of each primer (Sangon Biotech Co., Ltd., Shanghai, China), $12.5 \mu \mathrm{l}$ of Taq PCR mix (Takara Biotechnology Co., Ltd.) and double distilled $\mathrm{H}_{2} \mathrm{O}$ to adjust the total volume to $25 \mu$ l. Initial denaturation occurred at $94^{\circ} \mathrm{C}$ for $3 \mathrm{~min}$, followed 

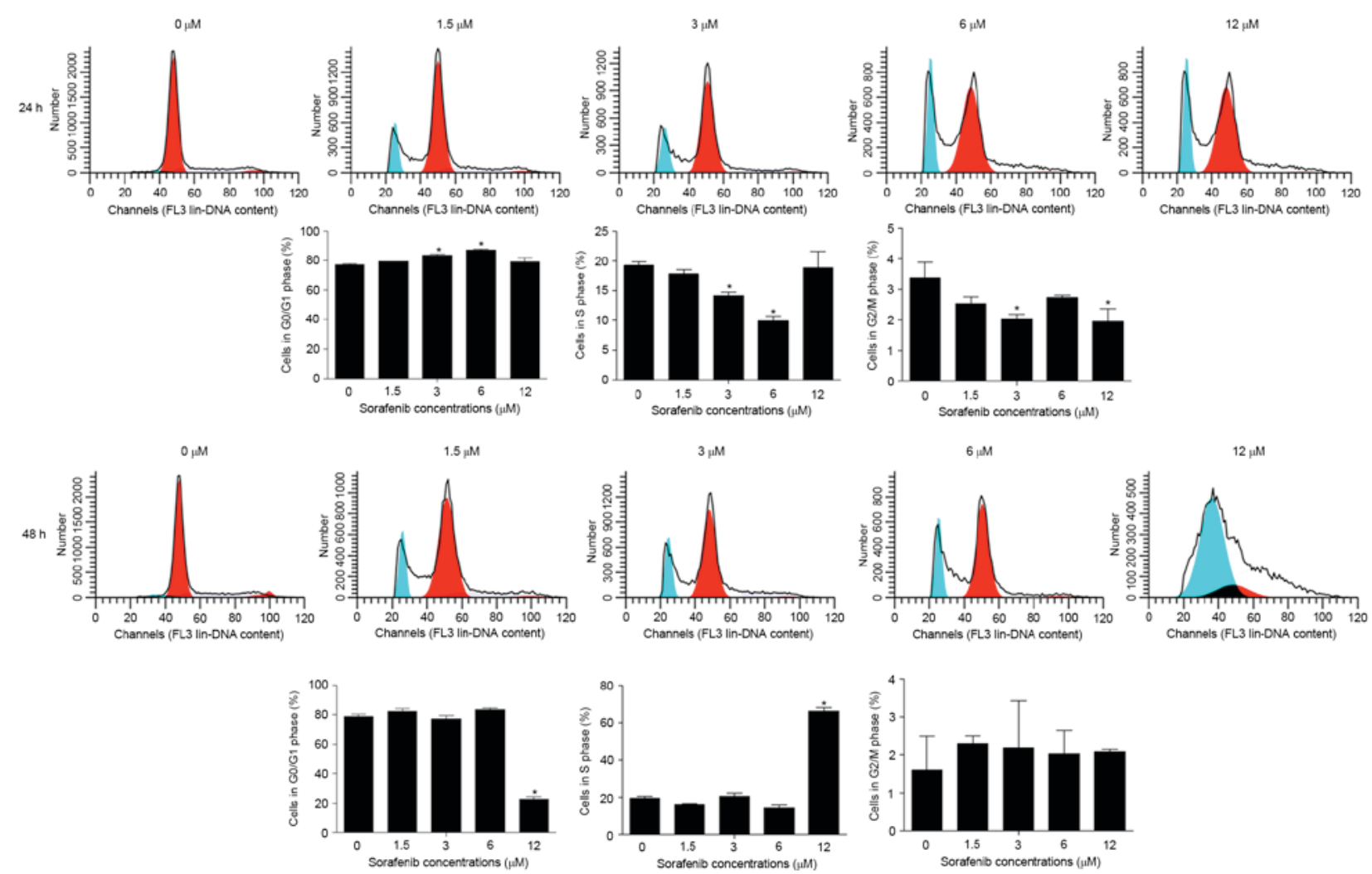

Figure 2. Cell cycle of NB4 cells treated with different concentrations of sorafenib. Flow cytometry analysis demonstrated that sorafenib increased the percentage of cells in the G0/G1 phase and decreased the percentage of cells in S phase following treatment for 24 or 48 h. Blue represents G0/G1 phase, and red represents $\mathrm{S}$ phase. ${ }^{\mathrm{P}}<0.05$, compared with the $0 \mu \mathrm{M}$ sorafenib treatment.

by $4030-\sec$ cycles at $94^{\circ} \mathrm{C}, 58^{\circ} \mathrm{C}$ and $74^{\circ} \mathrm{C}$, respectively. Elongation followed at $74^{\circ} \mathrm{C}$ for $10 \mathrm{~min}$. The PCR product was visualized using agarose gel (1.5\%), and analyzed on a UV trans-illuminator (UVitec Ltd., Cambridge, UK). Subsequently, sqPCR analysis was performed using the ratio of grey density associated with target genes to that associated with the internal control. mRNA was quantified using Labworks ${ }^{\mathrm{TM}}$ Analysis Software (version 4.5; Upland, CA, USA).

Western blot analysis. Cells were treated with sorafenib at a final concentration of $0,3,6$, or $12 \mu \mathrm{M}$ for $48 \mathrm{~h}$. Subsequently, cells were collected and lysed using radioimmunoprecipitation assay buffer (Beyotime Institute of Biotechnology, Haimen, China). A bicinchoninic acid protein assay kit based on the standard curve was used to determine the protein concentration. An equal amount of protein $(30 \mu \mathrm{g})$ per lane was separated using SDS-PAGE (10-15\% gel). Following electrophoresis, the separated proteins were transferred onto a polyvinylidene fluoride membrane. The membranes were subsequently blocked with $5 \%$ skim milk for $2 \mathrm{~h}$ at room temperature, and incubated with rabbit anti-rat MCL1 (cat. no. SAB4501843), caspase-3 (cat. no. C8487), caspase-8 (cat. no. C2976), cyclin D1 (cat. no. SAB4503501), MEK (cat. no. SAB4501863), phosphorylated (P)-MEK (cat. no. M7683), ERK (cat. no. M7556) or P-ERK (cat. no. M7933) polyclonal antibodies (1:500; Sigma-Aldrich; Merck KGaA), or rabbit anti-rat $\beta$-actin monoclonal antibody (cat. no. SAB5500001; 1:1,000, Sigma-Aldrich; Merck KGaA) at $4^{\circ} \mathrm{C}$ overnight. $\beta$-actin was used as an internal control. Following washing with PBS, the membrane was incubated with horseradish peroxidase-conjugated goat anti-rabbit secondary antibody (cat. no. A16110; 1:10,000; Thermo Fisher Scientific, Inc., Waltham, MA, USA) for $2 \mathrm{~h}$ at room temperature. The membrane was subsequently washed with PBS and developed using 3,3'-diaminobenzidine (Shanghai Sangong Pharmaceutical Co., Ltd.). Image Pro Plus software (version 6.3, Media Cybernetics, Inc., Rockville, MD, USA) was used to detect target protein expression.

Statistical analysis. SPSS software (Version 16.0; SPSS, Inc., Chicago, IL, USA) was used to analyze data. All experiments were repeated three times. All data were expressed as mean \pm standard deviation. One-way analysis of variance (ANOVA) was used to analyze data among different time points. Data among different concentrations of sorafenib were analyzed using one-way ANOVA. The Bonferroni method was used for pairwise comparison. $\mathrm{P}<0.05$ was considered to indicate a statistically significant difference.

\section{Results}

Effect of sorafenib on NB4 cell proliferation. MTT analysis demonstrated that, compared with untreated cells, $1.5-12 \mu \mathrm{M}$ of sorafenib significantly inhibited the proliferation of NB4 cells following treatment for 24,48 , or $72 \mathrm{~h}(\mathrm{P}<0.05)$. Furthermore, the inhibiting effect of sorafenib on NB4 cells was dose- and time-dependent $(\mathrm{P}<0.01$; Fig. 1). The results of cell cycle analysis demonstrated that, compared with untreated 

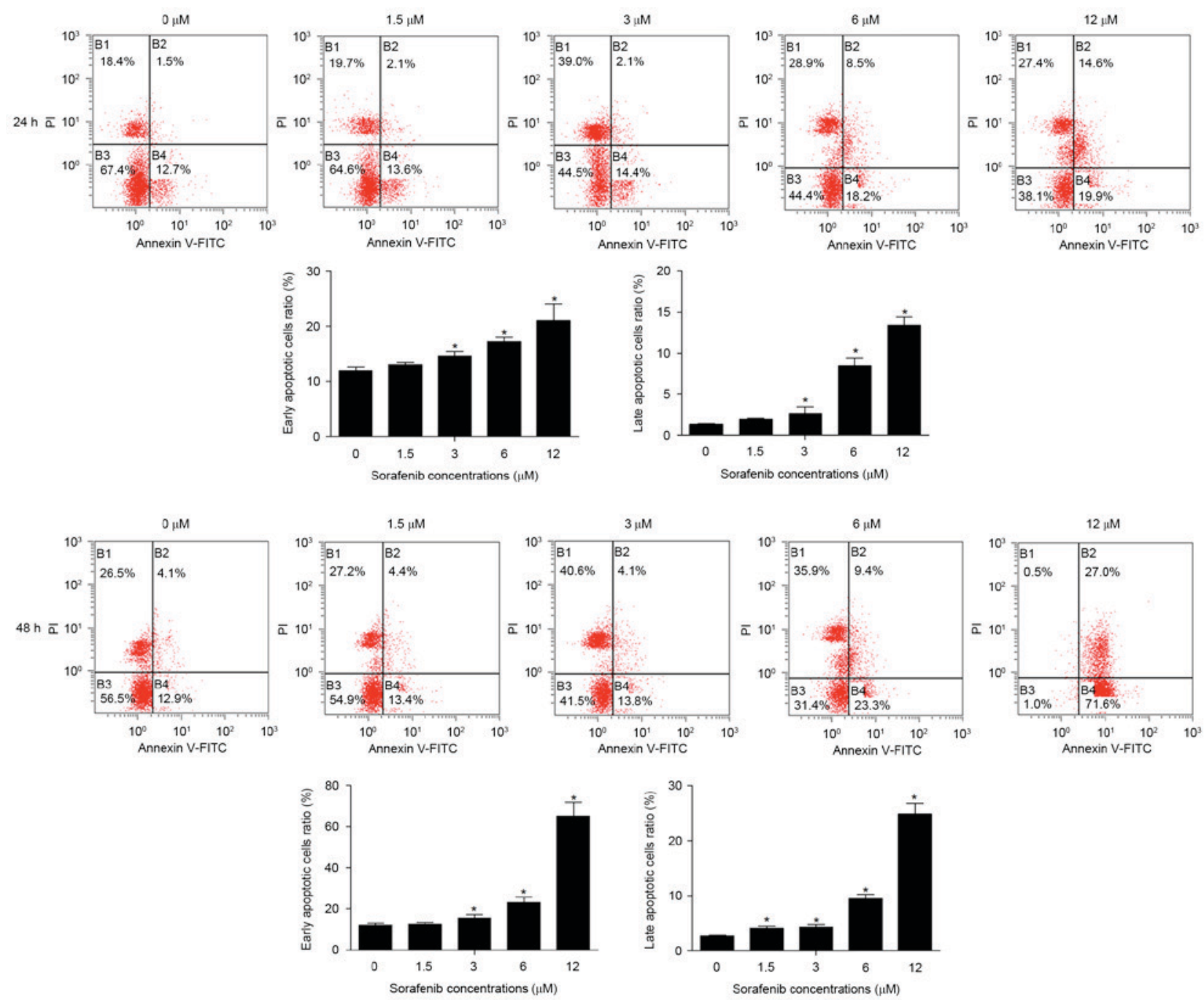

Figure 3. Apoptosis of NB4 cells treated with different concentrations of sorafenib. Flow cytometry analysis demonstrated that sorafenib induced the early and late apoptosis of cells following treatment for 24 or $48 \mathrm{~h}$. "P $<0.05$, compared with the $0 \mu \mathrm{M}$ sorafenib treatment. PI, propidium iodide; FITC, fluorescein isothiocyanate.

cells, the sorafenib-treated NB4 cells exhibited a significantly increased percentage of cells in the G0/G1 phase, but a significantly decreased percentage of cells in $\mathrm{S}$ phase $(\mathrm{P}<0.05$; Fig. 2), suggesting sorafenib may induce cell cycle arrest in the G0/G1 phase of NB4 cells.

Effect of sorafenib on NB4 cell apoptosis. Compared with untreated cells, the early and late apoptotic cells ratio was significantly increased in NB4 cells treated with 1.5-12 $\mu \mathrm{M}$ of sorafenib for 24 or $48 \mathrm{~h}$ (Fig. 3), and sorafenib induced an increase in NB4 cell apoptosis dose-dependently $(\mathrm{P}<0.05)$. These results suggest that sorafenib may induce apoptosis in NB4 cells.

Effect of sorafenib on the expression of MCL1, caspase-8, caspase-3 and cyclin D1 in NB4 cells. Compared with untreated cells, sorafenib significantly increased the mRNA and protein expression of caspase- 3 and caspase- 8 , and inhibited the expression of MCL1, following treatment for $48 \mathrm{~h}$ ( $\mathrm{P}<0.05$; Fig. 4). In addition, the expression of cyclin D1 was decreased in NB4 cells treated with $1.5-12 \mu \mathrm{M}$ of sorafenib for 24 and $48 \mathrm{~h}$ compared with that in untreated cells $(\mathrm{P}<0.05$;
Fig. 4B). Sorafenib induced alterations to the expression of each of these genes dose-dependently $(\mathrm{P}<0.05)$.

Effect of sorafenib on the MEK/ERK signaling pathway in NB4 cells. To further assess the mechanisms underlying the effects of sorafenib, the present study detected the expression of MEK/ERK signaling pathway-associated proteins in sorafenib-treated NB4 cells. The results of the present study demonstrated that, compared with untreated cells, sorafenib significantly inhibited the expression of P-MEK and P-ERK $(\mathrm{P}<0.05$; Fig. 5), and that the expression of P-MEK and P-ERK decreased with increasing sorafenib concentration $(\mathrm{P}<0.05)$.

\section{Discussion}

Due to the toxicity, side effects, possibility of APL drug resistance or relapse associated with APL chemotherapy (15), developing APL chemotherapy drugs that may overcome drug resistance is crucial. The present study demonstrated that, in NB4 cells, sorafenib inhibited cell growth, induced cell cycle arrest in the G0/G1 phase and apoptosis dose-dependently. Such 

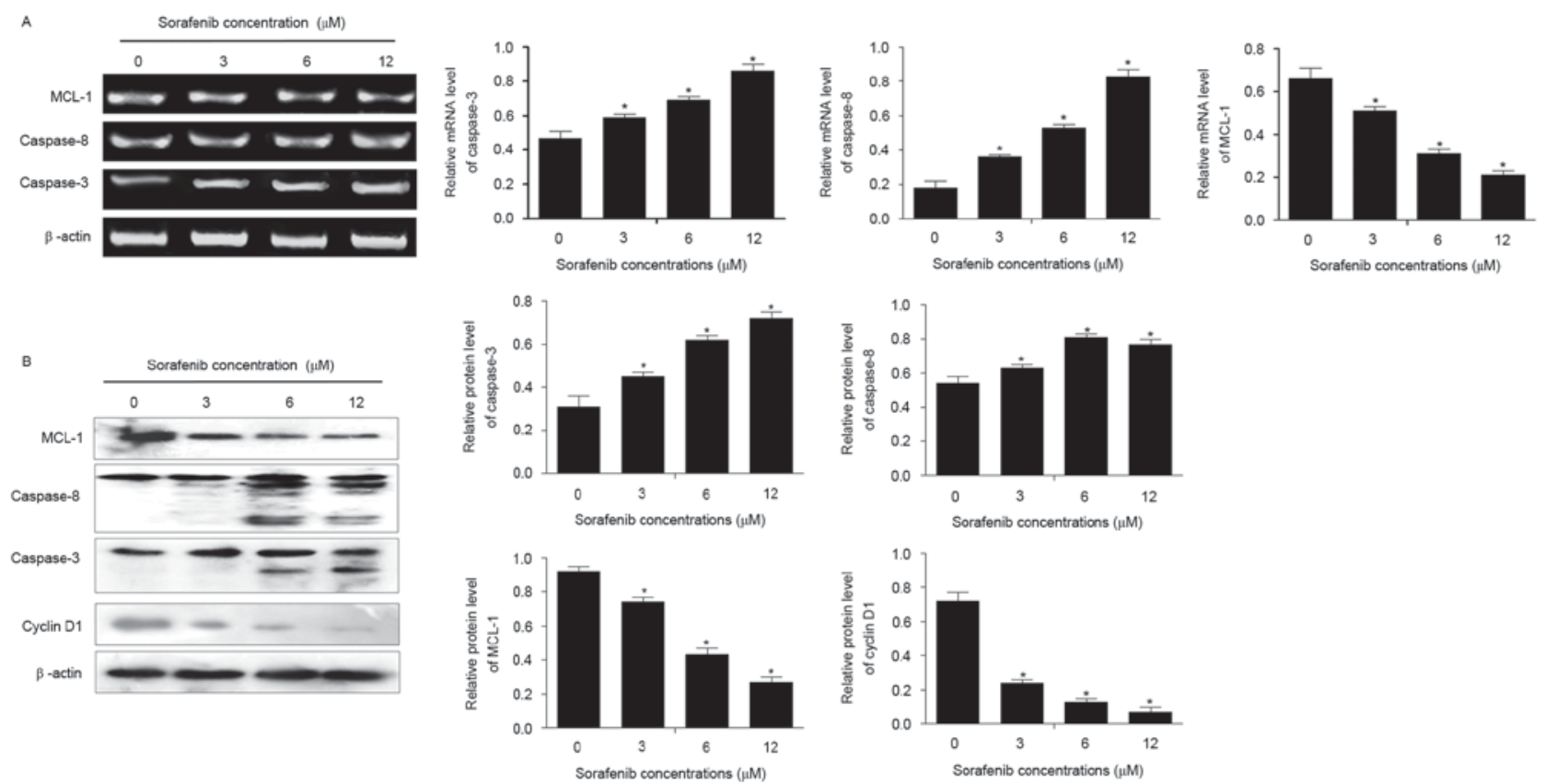

Figure 4. Expression of apoptosis-associated genes and cell cycle-associated genes in NB4 cells treated with different concentrations of sorafenib for $48 \mathrm{~h}$. (A) Semi-quantitative polymerase chain reaction and (B) western blot analysis demonstrated that sorafenib increased the expression of caspase-8 and caspase-3, and decreased the expression of MCL1 and cyclin D1. ${ }^{*} \mathrm{P}<0.05$, compared with the $0 \mu \mathrm{M}$ sorafenib treatment. MCL, myeloid cell leukemia.
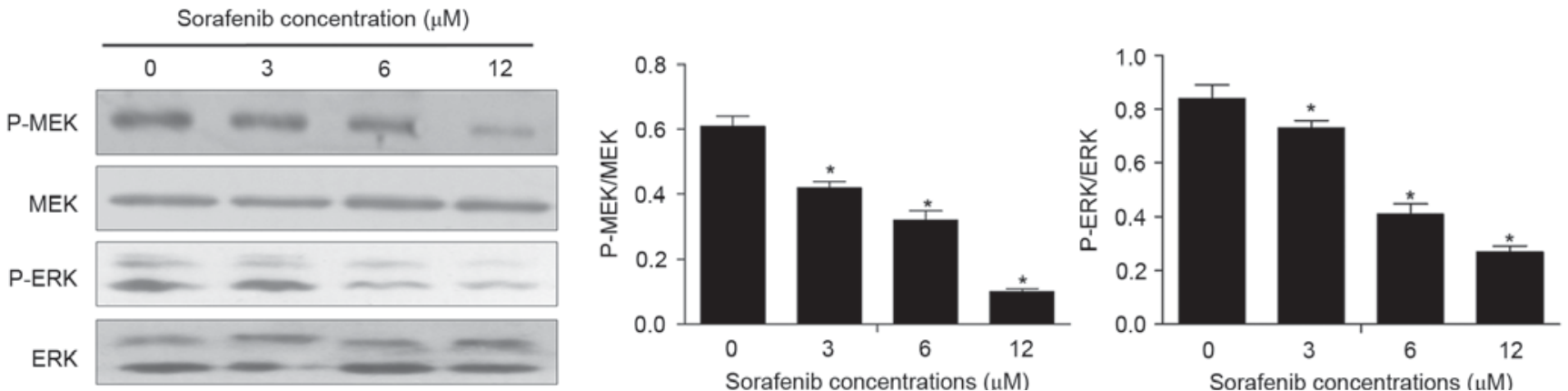

Figure 5. P-MEK/MEK and P-ERK/ERK protein expression in NB4 cells treated with different concentrations of sorafenib for $48 \mathrm{~h}$. Western blot analysis demonstrated that sorafenib inhibited the phosphorylation of MEK and ERK. ${ }^{*} \mathrm{P}<0.05$, compared with the $0 \mu \mathrm{M}$ sorafenib treatment. P, phosphorylated; MEK, mitogen-activated protein kinase; ERK, extracellular signal-regulated kinase.

effects may be induced by the upregulation of the proapoptotic proteins caspase- 3 and caspase- 8 , and the downregulation of the antiapoptotic protein MCL1 and the cell cycle-associated protein cyclin D1. Furthermore, sorafenib inhibited the phosphorylation of MEK and ERK.

Sorafenib is a novel multi-target anticancer drug that may simultaneously inhibit multiple cell surface and intracellular kinases that serve key functions in regulating tumor growth (16). A previous study demonstrated that sorafenib inhibited the RAF/MEK/ERK signaling pathway to directly exert an antitumor effect, and suppressed the expression of vascular endothelial growth factor receptor to inhibit tumor angiogenesis and thereby indirectly inhibit tumor cell growth in hepatocellular carcinoma (16). The present study demonstrated that sorafenib inhibited the proliferation of NB4 cells by promoting cell cycle arrest in the G0/G1 phase, a similar result to the effect of sorafenib on human synovial sarcoma cells, as demonstrated by Peng et al (17). Cyclin D1 is a key protein in cell cycle progression (18). The present study demonstrated that cyclin D1 was downregulated in sorafenib-treated cells compared with untreated cells, indicating that cyclin D1 may be associated with sorafenib-inhibited cell growth. In addition, the present study demonstrated that sorafenib-induced cell apoptosis may be associated with the expression of the apoptosis-associated proteins caspase-3, caspase- 8 and MCL1. A previous study suggested a proapoptotic effect of sorafenib on the human myeloma cell line RPMI8226 (19). Furthermore, Schult et al (20) demonstrated that sorafenib induced cell apoptosis by upregulating the expression of caspase- 3 and caspase-7 in acute lymphoblastic leukemia cells. In addition, Meng et al (21) suggested that MCL1 is an antiapoptotic B-cell lymphoma (Bcl)-2 homolog that aids the inhibitory apoptosis function of sorafenib in acute myelogenous leukemia. Combined with the results of the present study, these results suggest that sorafenib serves an inhibitory function in the development of APL by modulating cell proliferation and apoptosis.

To further assess the molecular mechanism underlying the activity of sorafenib in APL cells, the present study detected 
MEK/ERK signaling pathway-associated protein expression. Previous studies have demonstrated that sorafenib inhibited tumor growth of certain types of cancer through the regulation of the RAF/MEK/ERK signaling pathway $(22,23)$. The RAF/MEK/ERK signaling pathway is associated with cell cycle progression and apoptosis in numerous cells, and mutations in the pathway may be associated with cancer (24). Multiple studies have demonstrated that the mediation of G1 arrest by certain cell cycle-associated genes, including p15, p16 and p21 depended on the RAF/MEK/ERK signaling pathway (25-27). In addition, Boucher et al (28). suggest that the MEK/ERK signaling pathway may inhibit apoptosis by regulating the expression of $\mathrm{Bcl}-2$ and MCL1 in human pancreatic cancer cells. The results of the present study suggest that the inhibitory effects of sorafenib on APL cells were potentially achieved by the downregulation of the activity of the MEK/ERK signaling pathway. Therefore, the present study suggests that the role of sorafenib in inhibiting cell growth in APL cells may be regulated by the MEK/ERK signaling pathway.

To conclude, the present study demonstrated that sorafenib inhibited proliferation and induced apoptosis in human APL cells, the underlying mechanism of which may involve the MEK/ERK signaling pathway. Further studies are required in order to fully understand the mechanism underlying the effect of sorafenib on APL cells.

\section{Acknowledgements}

The authors would like to thank Dr Kai Hu, Mr Fei Gao, Mr Xiaobo Zhang and Ms Lu Wang (Institute of Hematology, Xi'an Central Hospital, Xi'an, Shaanxi, China), and Dr Bingcheng Liu and Ms Yuan Li (Leukemia Center, Institute of Hematology and Blood Diseases Hospital, Chinese Academy of Medical Sciences, Tianjin, China) for their assistance. The present study was supported by the Science and Technology Research and Development Program of Shaanxi Province (grant no. 2014K11-01-01-16).

\section{References}

1. Siegel RL, Miller KD and Jemal A: Cancer statistics, 2015. CA Cancer J Clin 65: 5-29, 2015.

2. Tallman MS: Acute promyelocytic leukemia. Best Pract Res Clin Haematol 27: 1, 2014.

3. Lo-Coco F, Avvisati G, Vignetti M, Thiede C, Orlando SM, Iacobelli S, Ferrara F, Fazi P, Cicconi L, Di Bona E, et al: Retinoic acid and arsenic trioxide for acute promyelocytic leukemia. $\mathrm{N}$ Engl J Med 369: 111-121, 2013.

4. Bally C, Fadlallah J, Leverger G, Bertrand Y, Robert A, Baruchel A, Guerci A, Recher C, Raffoux E, Thomas X, et al: Outcome of acute promyelocytic leukemia (APL) in children and adolescents: An Analysis in two consecutive trials of the European APL Group. J Clin Oncol 30: 1641-1646, 2012.

5. Takeshita A, Shigeno K, Shinjo K, Naito K, Ohnishi K, Hayashi H, Tanimoto $\mathrm{M}$ and Ohno R: All-trans retinoic acid (ATRA) differentiates acute promyelocytic leukemia cells independently of P-glycoprotein (P-gp) related multidrug resistance. Leuk Lymphoma 42: 739-746, 2001.

6. Wilhelm SM, Carter C, Tang L, Wilkie D, McNabola A, Rong H, Chen C, Zhang X, Vincent P, McHugh M, et al: BAY 43-9006 exhibits broad spectrum oral antitumor activity and targets the RAF/MEK/ERK pathway and receptor tyrosine kinases involved in tumor progression and angiogenesis. Cancer Res 64: 7099-7109, 2004.
7. Adnane L, Trail PA, Taylor I and Wilhelm SM: Sorafenib (BAY 43-9006, Nexavar), a dual-action inhibitor that targets RAF/MEK/ERK pathway in tumor cells and tyrosine kinases VEGFR/PDGFR in tumor vasculature. Methods Enzymol 407: 597-612, 2006.

8. Shimizu S, Takehara T, Hikita H, Kodama T, Miyagi T, Hosui A, Tatsumi T, Ishida H, Noda T, Nagano $\mathrm{H}$, et al: The let-7 family of microRNAs inhibits Bcl-xL expression and potentiates sorafenib-induced apoptosis in human hepatocellular carcinoma. J Hepatol 52: 698-704, 2010.

9. Panka DJ, Wang W, Atkins MB and Mier JW: The Raf inhibitor BAY 43-9006 (Sorafenib) induces caspase-independent apoptosis in melanoma cells. Cancer Res 66: 1611-1619, 2006.

10. Yang F, Brown C, Buettner R, Hedvat M, Starr R, Scuto A, Schroeder A, Jensen M and Jove R: Sorafenib induces growth arrest and apoptosis of human glioblastoma cells through the dephosphorylation of signal transducers and activators of transcription 3. Mol Cancer Ther 9: 953-962, 2010.

11. Zhang W, Konopleva M, Ruvolo VR, McQueen T, Evans RL, Bornmann WG, McCubrey J, Cortes J and Andreeff M: Sorafenib induces apoptosis of AML cells via Bim-mediated activation of the intrinsic apoptotic pathway. Leukemia 22: 808-818, 2008

12. Ravandi F, Cortes JE, Jones D, Faderl S, Garcia-Manero G, Konopleva MY, O'Brien S, Estrov Z, Borthakur G, Thomas D, et al: Phase I/II study of combination therapy with sorafenib, idarubicin, and cytarabine in younger patients with acute myeloid leukemia. J Clin Oncol 28: 1856-1862, 2010.

13. Pratz KW, Cho E, Levis MJ, Karp JE, Gore SD, McDevitt M, Stine A, Zhao M, Baker SD, Carducci MA, et al: A pharmacodynamic study of sorafenib in patients with relapsed and refractory acute leukemias. Leukemia 24: 1437-1444, 2010.

14. Ravandi F, Alattar ML, Grunwald MR, Rudek MA, Rajkhowa T, Richie MA, Pierce S, Daver N, Garcia-Manero G, Faderl S, et al: Phase 2 study of azacytidine plus sorafenib in patients with acute myeloid leukemia and FLT-3 internal tandem duplication mutation. Blood 121: 4655-4662, 2013.

15. Gallagher RE, Moser BK, Racevskis J, Poiré X, Bloomfield CD, Carroll AJ, Ketterling RP, Roulston D, Schachter-Tokarz E, Zhou DC, et al: Treatment-influenced associations of PML-RAR $\alpha$ mutations, FLT3 mutations, and additional chromosome abnormalities in relapsed acute promyelocytic leukemia. Blood 120: 2098-2108, 2012.

16. Liu L, Cao Y, Chen C, Zhang X, McNabola A, Wilkie D, Wilhelm S, Lynch $M$ and Carter C: Sorafenib blocks the RAF/MEK/ERK pathway, inhibits tumor angiogenesis, and induces tumor cell apoptosis in hepatocellular carcinoma model PLC/PRF/5. Cancer Res 66: 11851-11858, 2006.

17. Peng CL, Guo W, Ji T, Ren T, Yang Y, Li DS, Qu HY, Li X, Tang S, Yan TQ and Tang XD: Sorafenib induces growth inhibition and apoptosis in human synovial sarcoma cells via inhibiting the RAF/MEK/ERK signaling pathway. Cancer Biol Ther 8: 1729-1736, 2009.

18. Johnson DG and Walker CL: Cyclins and cell cycle checkpoints. Annu Rev Pharmacol Toxicol 39: 295-312, 1999.

19. Zhou NC, Liu BL, Qi MY, Xu B and Liu X: Effects of sorafenib on proliferation and apoptosis of human multiple myeloma cell RPMI 8226. Zhongguo Shi Yan Xue Ye Xue Za Zhi 22: 1331-1335, 2014 (In Chinese).

20. Schult C, Dahlhaus M, Ruck S, Sawitzky M, Amoroso F, Lange S, Etro D, Glass A, Fuellen G, Boldt S, et al: The multikinase inhibitor Sorafenib displays significant antiproliferative effects and induces apoptosis via caspase 3,7 and PARP in Band T-lymphoblastic cells. BMC cancer 10: 560, 2010.

21. Meng XW, Lee SH, Dai H, Loegering D, Yu C, Flatten K, Schneider P, Dai NT, Kumar SK, Smith BD, et al: Mcl-1 as a buffer for proapoptotic Bcl-2 family members during TRAIL-induced apoptosis: A mechanistic basis for sorafenib (bay 43-9006)-induced TRAIL sensitization. J Biol Chem 282: 29831-29846, 2007.

22. Tang K, Luo C, Li Y, Lu C, Zhou W, Huang H and Chen X: The study of a novel sorafenib derivative HLC-080 as an antitumor agent. PLoS One 9: e101889, 2014.

23. Locatelli SL, Giacomini A, Guidetti A, Cleris L, Mortarini R, Anichini A, Gianni AM and Carlo-Stella C: Perifosine and sorafenib combination induces mitochondrial cell death and antitumor effects in NOD/SCID mice with Hodgkin lymphoma cell line xenografts. Leukemia 27: 1677-1687, 2013. 
24. Chang F, Steelman LS, Shelton JG, Lee JT, Navolanic PM, Blalock WL, Franklin $R$ and McCubrey JA: Regulation of cell cycle progression and apoptosis by the Ras/Raf/MEK/ERK pathway (Review). Int J Oncol 22: 469-480, 2003.

25. Blalock WL, Weinstein-Oppenheimer C, Chang F, Hoyle PE, Wang XY, Algate PA, Franklin RA, Oberhaus SM, Steelman LS and McCubrey JA: Signal transduction, cell cycle regulatory, and anti-apoptotic pathways regulated by IL-3 in hematopoietic cells: Possible sites for intervention with anti-neoplastic drugs. Leukemia 13: 1109-1166, 1999.

26. Chang F and McCubrey JA: P21(Cip1) induced by Raf is associated with increased Cdk4 activity in hematopoietic cells. Oncogene 20: 4354-4364, 2001.
27. Malumbres M, Pérez De Castro I, Hernández MI, Jiménez M, Corral T and Pellicer A: Cellular response to oncogenic ras involves induction of the Cdk4 and Cdk6 inhibitor p15(INK4b). Mol Cell Biol 20: 2915-2925, 2000.

28. Boucher MJ, Morisset J, Vachon PH, Reed JC, Lainé J and Rivard N: MEK/ERK signaling pathway regulates the expression of Bcl-2, Bcl-X(L), and Mcl-1 and promotes survival of human pancreatic cancer cells. J Cell Biochem 79: 355-369, 2000.

This work is licensed under a Creative Commons Attribution-NonCommercial-NoDerivatives 4.0 International (CC BY-NC-ND 4.0) License. 